\title{
Earnings Quality and Investment Efficiency: Evidence from Eastern Europe
}

\section{Victoria Cherkasova, Daryush Rasadi ${ }^{1}$}

\begin{abstract}
This study explores the firm-level relationship between earnings quality and investment efficiency. Higher quality of reported results has the capacity to positively impact the efficiency of company's investment levels by over- and underinvestment reduction. The research is carried out on the sample of 7546 companies from Eastern Europe for the period 2010-2015. Eastern European countries have a unique institutional and business environment that is relevant to the purpose of this paper. We divide the sample into 2 fundamentally different economic sectors - industrial and retail - and test the significance of each factor in the main relationship. We also examine the factor of the firm's ownership form by comparing earnings quality with investment efficiency values between public and private companies. Our main results show that a higher earnings quality mitigates both overinvestment and underinvestment issues. The relationship between earnings quality and underinvestment turns out to be stronger in the industrial sector. As for the comparison of public and private firms, public companies on average demonstrate a higher earnings quality and lower overinvestment issues.
\end{abstract}

Key words: Earnings quality, financial reporting quality, investment efficiency, overinvestment, underinvestment

JEL Classification: G31, G32

Received: 29 May 2017 / Accepted: 13 October 2017 / Sent for Publication: 8 December 2017

\section{Introduction}

The execution of efficient investment decisions is a vital objective for most companies as it facilitates a sustainable growth and contributes to the maximization of stakeholder wealth. The rapid development of capital markets in Eastern Europe and other regions worldwide opens new financing opportunities for corporates in the form of equity, debt, or other mixed and structured financial products. Such an exposure to a large pool of creditors and shareholders places certain restrictions and stricter regulations upon the management's decision-making, but, at the same time, it might be a source of strong

\footnotetext{
${ }^{1}$ National Research University Higher School of Economics (NRU HSE), Faculty of Economic Sciences, Department of Finance, 26 Shabolovka St. Building 3, 119049 Moscow, Russia; vcherkasova@hse.ru (corresponding author), daryush.rasadi@gmail.com
}

(C) 2017 by the authors; licensee Review of Economic Perspectives / Národohospodářský obzor, Masaryk University, Faculty of Economics and Administration, Brno, Czech Republic. This article is an open access article distributed under the terms and conditions of the Creative Commons Attribution 3.0 license, Attribution - Non Commercial - No Derivatives. 
information asymmetry issues and agency conflicts. These conditions, together with some Eastern Europe-specific institutional properties such as a high ownership concentration or a massive impact of government on business, bring investment efficiency issues to the fore: it is a challenge and a crucial problem for companies to maintain optimal investment levels and make efficient investment decisions in a modern institutional environment.

Due to its relevance, practicality and relatability, the problem of efficient (or optimal) investments of firms is of a great interest to scholars. Some of the most relevant and widely considered topics in this field are related to the impact of various factors on the efficiency of the company's investment decisions. This study is devoted to one of the major factors with such an influence potential - the quality of company's earnings.

The 2008-2009 financial crisis raised many questions concerning the quality of companies' reporting and significantly increased the demand for transparency, sustainability and lack of earnings management.

Theoretical frameworks as well as the empirical research imply that the firm's earnings quality (along with the overall financial reporting quality) plays a significant role in mitigating suboptimal investment issues. Higher earnings quality reduces information asymmetry between managers and stockholders, which leads to an enhanced institutional environment and a decreased probability of agency conflicts arising (Bushman and Smith, 2001; Healy and Palepu, 2001). Financial information of a higher quality, being more unbiased, also improves the environment for planning and valuation. On the other hand, earnings management distorts available information as well as managers' incentives, leading to inefficient investments (McNichols and Stubben, 2008).

This study explores the relationship between earnings quality and investment efficiency on a sample of companies from Eastern Europe for the period 2010-2015. Investment efficiency problem is divided into over- and underinvestment. We narrow the sample to the companies of two fundamentally different economic sectors - industrial and retail and conduct research on the extent of significance of such factor in the main relationship. We also account for the factor of firm's ownership form and examine how earnings quality and investment efficiency differ between public and private firms.

The main goal of this paper is to determine the presence and strength of the impact of earnings quality on investment efficiency for industrial and retail companies of Eastern Europe.

The topic of the role of firm's financial reporting quality in the efficiency of its investment decisions is quite well developed in the literature. The first empirical work in this field of study was produced by Biddle and Hilary (2006) on a sample of public US companies, and later studies were building up on this fundamental work. Biddle, Hilary, and Verdi (2009) were the first to separate inefficient investments into over- and underinvestment, while Chen, Hope, Li, and Wang (2011) transferred the research to emerging markets and private firms. Recent papers focus on the local samples and consider additional factors that may alter the main relationship, such as debt maturity (Cutillas Gomariz and Sánchez Ballesta, 2014) or free cash flow (Fusheng, Zhibiao, and John, 2015). 
However, our knowledge of the effect of earnings quality on investment efficiency is not comprehensive yet. Our study contributes to the topic in two major ways: firstly, we expand the geographical coverage of already existing research by choosing Eastern Europe companies as our sample. Eastern Europe is the largest geopolitical region of Europe and we consider it to have a unique institutional environment compared to the samples from prior studies: local firms have a strongly concentrated ownership structure, which diminishes the value of accounting information (Ball, Kothari, and Robin, 2000). Also, the vast majority of companies are private (Gugler, Ivanova, and Zechner, 2014), which also affects the quality and role of financial information. Moreover, in Eastern Europe a massive number of companies is state-owned or state-financed (Gugler et al., 2014), especially in the industrial sector, which is also a unique institutional feature.

Secondly, we focus our research on the previously ignored factor of different economic sectors (namely industrial and retail). We suppose that this factor can significantly alter the main relationship because of the fundamental differences between the two sectors: companies in the industrial sector of Eastern Europe are usually larger and tend to rely on accrual accounting more (Allee and Yohn, 2009), often have better access to capital markets (there are dramatically more public industrial firms than retail ones) and are more likely to have big financial departments and execute complex long-term investment decisions. All the evidence suggests a stronger relationship between earnings quality and investment efficiency in the industrial sector.

The study proceeds as follows. Sections 2 and 3 provide a review of prior literature on the topics of earnings quality, investment efficiency and their relationship, and present the development of our hypotheses. Section 4 contains sample description. Section 5 contains the complete research design, which includes descriptions of proxies, regression models and variables. Section 6 describes main results of the research. Section 7 presents the conclusion of the study.

\section{Literature review}

The impact of the quality of company's earnings on the efficiency of its investment decisions has been a recurring topic in academic literature over the past decade. Vast research shows that companies may mitigate some agency problems (such as moral hazard or adverse selection), reduce the probability of agency conflicts and enhance institutional environment by improving their earnings quality as well as overall financial reporting quality (Bushman and Smith, 2001; Chen et al., 2011; Healy and Palepu, 2001; etc.). Due to the reduction of information asymmetry, managers are able to make more efficient and profitable investment decisions (Cutillas Gomariz and Sánchez Ballesta, 2014). However, prior to the examination of papers from this field, it is crucial to explain two main constituents of the considered relationship.

\subsection{Earnings quality}

The issue of correctly defining the company's earnings quality has been subjected to scrutiny among researchers. According to Dechow, Ge, and Schrand (2010), earnings quality (from now on referred to as "EQ") is one of the two main components of the overall financial reporting quality, along with the quality of the presentation of information. Information of a high quality is decision-useful and faithfully represents eco- 
nomic reality, whereas a high quality of reported results (or high quality of earnings) implies a sustainable activity, adequate returns and a lack of manipulation.

While the quality of presentation is, to a large extent, a subjective metric, EQ is more objective and easier to quantify. However, there is no true single approach to evaluation of EQ (Md. Shamimul, Normah, and Syed Zabid, 2015). There are numerous methods of evaluating the quality of firm's reported results, such as earnings persistence models (see Sloan, 1996), earnings smoothness models (see Collins, Kothari, Shanken, and Sloan, 1994), or timely loss recognition models (see Basu, 1997).

Nonetheless, one particular type of models is associated with further consideration of relationship with investment efficiency more frequently than others: accrual models. Ohlson (2014) defines accruals as a non-cash constituent of earnings. The method is based on the accrual method of accounting that provides the company with opportunities of managing financial results, which, along with the incentives arising from agency conflicts, information asymmetry and financial problems, may lead to the abuse of accrual accounting. Thus, higher discretionary (unnatural) accruals (that are measured using regression models as a deviation from the expected value of accruals) indicate earnings management or errors in estimation and, in any case, represent lower EQ.

The first accrual-based model was proposed by Jones (1991), while a fundamentally different cash-flow approach was presented by Dechow and Dichev (2002). These two basic models have since been subject to some alterations that also rely on the theoretical basis. Table 1 presents an overview of major accrual-based models used to estimate EQ.

Table 1 Overview of major accrual-based models

\begin{tabular}{|c|c|c|}
\hline Author(s) & Model regressors $\left(X_{i}\right)$ & Notes \\
\hline Jones (1991) & $\Delta$ Revenue, PPE & Basic model \\
\hline $\begin{array}{l}\text { Dechow, Sloan, and Sweeney } \\
\text { (1995) }\end{array}$ & $\begin{array}{c}\text { ( } \Delta \text { Revenue w/o credit sales), } \\
\text { PPE }\end{array}$ & $\begin{array}{c}\text { Modification of Jones (1991) } \\
\text { model }\end{array}$ \\
\hline Dechow and Dichev (2002) & $\mathrm{CFO}_{\mathrm{t}-1}, \mathrm{CFO}_{\mathrm{t}}, \mathrm{CFO}_{\mathrm{t}+1}$ & Basic model \\
\hline McNichols (2002) & $\begin{array}{l}\mathrm{CFO}_{\mathrm{t}-1}, \mathrm{CFO}_{\mathrm{t}}, \mathrm{CFO}_{\mathrm{t}+1} \\
\quad \Delta \text { Revenue, PPE }\end{array}$ & $\begin{array}{l}\text { Modification of Dechow and } \\
\text { Dichev (2002) model } \\
\text { Decomposing of the standarc }\end{array}$ \\
\hline $\begin{array}{l}\text { Francis, Schipper, and Vincent } \\
(2005)\end{array}$ & As in McNichols (2002) & $\begin{array}{l}\text { deviation of the residuals into } \\
\text { natural and discretionary } \\
\text { components }\end{array}$ \\
\hline $\begin{array}{l}\text { Kothari, Leone, and Wasley } \\
(2005)\end{array}$ & $\triangle$ Revenue, PPE, ROA & $\begin{array}{c}\text { Modification of Jones (1991) } \\
\text { model }\end{array}$ \\
\hline
\end{tabular}

Source: authors' investigation. Note: residuals of the models (discretionary accruals) are used as proxies for $E Q$.

Dechow et al. (2010) provide a profound classification of accrual-based and other models for calculating EQ, together with pros and cons of various approaches. Many authors use several different models in their research, as it is extremely difficult to choose one, or combine them by making standardized averages. 


\subsection{Investment efficiency}

The viewpoint that problems associated with investment inefficiency (from now on referred to as "IE") arise from market imperfections such as information asymmetry or specific agency costs has a widespread appeal within a scientific context. According to Tobin (1969) and later neoclassical interpretations of his studies (Abel, 1983; Hayashi, 1982), firms rely on marginal value of investment when making investment decisionsas it guarantees optimal capital distribution. However, Keynesian and agency theories contradict this point of view (Myers, 1977; Myers and Majluf, 1984). Market frictions such as taxes, as well as asymmetry of information and arising conflicts among managers, shareholders and debtholders, may result in companies making suboptimal ${ }^{2}$ investment decisions. Such decisions lead to deviations from optimal levels of investment for the company in the form of over- and underinvestment, which means accepting NPV-negative projects (overinvestment, also referred to as "OI") or rejecting NPVpositive projects (underinvestment, also referred to as "UI") (McNichols and Stubben, 2008). Apart from agency problems such as adverse selection or moral hazard, inefficient investment decisions may also simply result from estimation errors in valuation or financial planning.

Cherkasova and Zakharova (2016) connect OI and UI with specific types of agency conflicts: risk shifting (a conflict between shareholders and debtholders) and empire building (a conflict of interest between managers and shareholders) effects are associated with OI, while debt overhang (a conflict between shareholders and debtholders) and risk avoidance (a conflict between shareholders and managers) lead to UI problems (see also La Rocca, Cariola, and La Rocca, 2007).

Within this framework, the (in)efficiency of investment decisions is consistently measured with the help of various regression models (using a certain amount of investment as a dependent variable and some of the firm's financials as factors): the residuals of the model stand for proxies for investment inefficiency (Biddle et al., 2009; Chen et al., 2011; Fusheng et al., 2015; etc.). The larger the absolute figures for residuals, the higher the deviation from the optimal investment level, with positive residuals implying overinvestment and negative residuals implying underinvestment. Table 2 presents an overview of major firm-level investment models used to estimate IE.

Before 2009, the common method in the IE area had been selecting investment-cash flow sensitivity and Tobin's Q as factors influencing investment levels, with the sensitivity coefficient working as a proxy for IE. In this context, Tobin's $Q$ is presented as a factor of investment opportunities, and investment-cash flow sensitivity indicates frictions and distortions in management decisions which result in a limited external funding and a consecutive reliance on internal funding, thus increasing the dependence from cash inflows (Biddle and Hilary, 2006). However, S. M. Fazzari, Hubbard, and Petersen (2000) raise some objective concerns about the relevance of this approach: increasing the investment-cash flow sensitivity does not necessarily result from the internal fund-

\footnotetext{
${ }^{2}$ In this context, terms "efficient" and "optimal" as well as "inefficient" and "suboptimal" are synonyms.
} 
ing of investments and financial constraints, just as internal funding is not always associated with OI or UI.

Table 2 Overview of major firm-level residual-based investment efficiency models

\begin{tabular}{lcc}
\hline Author(s) & Model regressors $\left(\mathrm{X}_{\mathrm{i}}\right)$ & Notes \\
\hline Biddle et al. (2009) & Revenue growth rate & $\begin{array}{c}\text { Were the first to apply this } \\
\text { method to firm-level invest- } \\
\text { ments }\end{array}$ \\
Chen et al. (2011) & $\begin{array}{c}\text { Revenue growth rate, size, age, } \\
\text { cash-to-assets ratio, leverage, } \\
\text { political, legal and business } \\
\text { constraint indices }\end{array}$ & $\begin{array}{c}\text { Include additional factors into } \\
\text { the model }\end{array}$ \\
Fusheng et al. (2015) & As in Chen et al. (2011) + lagged \\
investment & $\begin{array}{c}\text { Include additional factor into } \\
\text { the model }\end{array}$ \\
\hline
\end{tabular}

Source: authors' investigation. Note: residuals of the models are used as proxies for IE.

\subsection{Relationship between earnings quality and investment efficiency}

One of the main objectives of financial reporting is to contribute to the optimal and efficient allocation of capital (Chen et al., 2011). Prior research suggests, both empirically and theoretically, that EQ as well as the overall financial reporting quality ${ }^{3}$ (from now on referred to as "FRQ") positively influences IE in a significant way. Such an influence may occur in various forms. First of all, a higher EQ reduces information asymmetry between managers and stockholders, which leads to decreased adverse selection costs (Bushman and Smith, 2001), reduced external financing costs (Fusheng et al., 2015) and enhanced contracts and monitoring (consequently mitigating a moral hazard problem) (Healy and Palepu, 2001). This means that managers are now less likely to make biased decisions or engage in agency conflicts like risk shifting, empire building, risk avoidance or debt overhang. Secondly, since financial information of a higher quality is more "truthful" and unbiased, all the predictions, planning and valuation executed by employees will better reflect the real situation with the company and therefore be more robust.

To sum up, a higher EQ leads to an improved institutional environment, decreased probability of agency conflicts and an enhanced environment for planning and valuation. On the other hand, earnings management distorts available information and managers' incentives, leading to suboptimal investment issues (McNichols and Stubben, 2008).

Biddle and Hilary (2006) produced a groundbreaking work that launched a new wave of research on investment efficiency: they were the first to consider firm-level capital

\footnotetext{
${ }^{3}$ Academic literature on this topic treats terms "earnings quality" and "financial reporting quality" as synonyms and does not differentiate between them. However, it's important to keep in mind that the latter term may have a more generic meaning and absorb the former one, while in this study we imply quality of reported results when using the term "financial reporting quality" or "FRQ".
} 
investment in connection to accounting quality. The study is carried out on a sample of US firms and arrives at a significant positive relation between IE and FRQ.

Throughout the years, the research on this subject has been expanding in various directions, carefully building up on this fundamental work. Biddle et al. (2009) were the first in this context to separate suboptimal investments into over- and underinvestment problems (using a model of growth opportunities). Apart from confirming the role of FRQ in mitigating both OI and UI, they find that a higher FRQ tends to boost investment of firms suffering from financial constraints and to restrain investment of unlevered and cash-rich companies. The sample is also restricted by US companies.

Chen et al. (2011) were the first to explore the relationship between EQ and IE among private firms in emerging markets. Their empirical results are consistent with prior studies. They further test some additional hypotheses and find that the relation strengthens in bank financing and weakens when the company follows tax-minimization incentives.

Recent investigations on the topic put forward new factors that may alter the main relationship. For example, Cutillas Gomariz and Sánchez Ballesta (2014) conduct a study (on a sample of Spanish firms) that examines the role of debt maturity in the IE problem. They find debt maturity to be a substitute for FRQ in the mechanism of IE enhancement: companies with higher levels of a short-term debt show lower impact of EQ on diminishing of suboptimal investments. Also, in this study FRQ turns out not to have any influence on underinvestment.

Another recent paper by Fusheng et al. (2015) investigates the role of free cash flow in the EQ-IE relationship. They use a sample of Chinese firms and their findings include a stronger association of FRQ with OI for companies with a large free cash flow.

McNichols and Stubben (2008) tackle the EQ-IE issue from a different perspective. They use a sample of public US companies with already established fraudulent or clear records and test whether firms that did earnings management and manipulation tend to have made less efficient investments. They find a significant impact of earnings management on investment efficiency.

Our study contributes to the topic by bringing the previously ignored factor of different economic sectors into the main relationship, as well as by expanding the geographic coverage of the existing research: prior literature does not use Eastern European countries in the samples.

The value of accounting information is lower in the countries with a more concentrated ownership structure (Ball et al., 2000). In Eastern Europe the concentration of control of public companies is high due to privatization processes, low transparency and corruption. Additionally, the vast majority of firms in Eastern Europe are private (Gugler et al., 2014), and according to Chen et al. (2011), private firms on average have a lower financial reporting quality and its role there is limited.

In Eastern Europe IFRS are not accepted or used as the main framework entirely; therefore, EQ will be lower as IFRS adoption tends to reduce earnings management (Dayanandan, Donker, Ivanof, and Karahan, 2016). 
Using this evidence, we can speculate that the quality of earnings as well as its impact on investment efficiency is lower in our sample compared to previous studies of developed markets.

Another distinct feature of our sample is a massive amount of state-owned companies, which is typical of Eastern Europe (Gugler et al., 2014). Overall, it can be concluded that our study operates in a different institutional context than previous papers do.

Also, previous studies fail to distinguish different sectors of economy in which companies operate. There are clear fundamental distinctions in operations and financial statements of the companies belonging to different industries and economic sectors, and such distinctions can significantly affect and alter the underlying relationship. In this study, we account for different economic sectors, retail and industrial, and conduct a research on the extent of significance of this factor. Industrial and retail sectors are considered to be on the opposite spectrums in various business aspects and it is hence desirable to compare them for the purpose of this paper.

There are many traces evidence that allow us to speculate about the significance of the economic sector factor. It is believed that smaller firms usually rely on accrual accounting less than larger firms (Allee and Yohn, 2009), and in Eastern Europe larger firms mostly represent the industrial sector, while small and mid-sized companies operate in retail and service sectors (Klapper, Sarria-Allende, and Sulla, 2002). A company which uses accrual accounting intensively and broadly should obtain a stronger relationship between EQ and efficiency of its investment decisions.

Moreover, in Eastern Europe the pool of public companies is mostly comprised of large industrial corporations and the majority of retail firms are private. Chen et al. (2011) argue that for private firms the role of FRQ in making investment decisions is limited. But, on the other hand, it cannot be completely ignored as there are fewer sources of information about internal or external decision-makers of private companies.

Finally, large industrial firms typically tend to thoroughly analyze financial reports and financial results prior to making investment decisions. Financial departments in such companies are often bigger and carry more responsibilities than the ones in retail companies.

\section{Hypotheses development}

After exploring prior topic-related papers, we propose a few hypotheses for our research. The major subject of this study is the relationship between EQ and IE, and our first hypothesis reflects that. The positive impact of EQ on both over- and underinvestment has been widely confirmed in prior studies (Biddle et al., 2009; Chen et al., 2011; Fusheng et al., 2015). One particular paper found the impact of EQ on UI to be insignificant (Cutillas Gomariz and Sánchez Ballesta, 2014), but, as of now, we consider it as an exception to the rule and a local sample phenomenon (the study was carried out on a sample of Spanish firms). EQ mitigates suboptimal investment problems through enhancing institutional environment, decreasing the probability of agency conflicts and improving the environment for planning and valuation.

Our first hypothesis is as follows: 


\section{H1: Higher earnings quality mitigates overinvestment/underinvestment.}

This hypothesis is tested for industrial and retail sub-samples and for OI and UI separately.

Our second hypothesis is connected to the distinctive feature of our research - the comparison of industrial and retail sectors of Eastern European countries. Industrial firms tend to rely on accrual accounting more that retail ones (Klapper et al., 2002); they are more likely to conduct long-term investment decisions based on financial reports and in Eastern Europe they use external financing more frequently (Allee and Yohn, 2009), which strengthens the role of EQ for them (Chen et al., 2011). Based on this evidence we can make the following conjecture:

H2: The relationship between earnings quality and overinvestment/underinvestment is stronger in the industrial sector (compared to the retail sector).

This hypothesis is tested for OI and UI separately.

Described above are the main hypotheses that we test in our research. To make the study more complex and coherent, we also pose several additional hypotheses that are concerned with the differences in EQ and IE between public and private companies of Eastern Europe:

H3: On average, public companies have higher earnings quality.

H4: On average, public companies have lower overinvestment/underinvestment.

The evidence that supports these two hypotheses has been presented in Chen et al. (2011). Public firms face higher demand for the quality of their financial results and investment decisions - they are exposed to shareholders and regulators - and have to operate accordingly; thus, the probability of earnings management as well as execution of inefficient investment decisions in public firms is lower.

Hypothesis H4 is tested for OI and UI separately.

\section{Sample description}

We use the Bureau van Dijk Amadeus database as the source of financial panel data. The database is specifically dedicated to European companies. To distinguish between economic sectors, we use NAICS 2012 classification integrated in Amadeus: the selected primary codes are 31-33 "Manufacturing" for the industrial sector and 44-45 "Retail Trade" for the retail sector. To select the appropriate countries we choose the "Eastern Europe" option of geographical classification in Amadeus. Our final sample consists of 7546 companies from 10 countries and provides a balanced distribution of companies between retail $(46.85 \%)$ and industrial $(53.15 \%)$ economic sectors, as demonstrated in Table 3: 
Table 3 Distribution of companies by country and sector

\begin{tabular}{|c|c|c|c|}
\hline Country & $\begin{array}{c}\text { Sector: Retail } \\
\text { Frequency } \\
\text { (Percent) }\end{array}$ & $\begin{array}{c}\text { Sector: Industrial } \\
\text { Frequency } \\
\text { (Percent) }\end{array}$ & $\begin{array}{c}\text { Total } \\
\text { Total } \\
\text { (Percent) }\end{array}$ \\
\hline Bosnia and Herzegovina & $\begin{array}{c}110 \\
(3.11)\end{array}$ & $\begin{array}{c}223 \\
(5.56)\end{array}$ & $\begin{array}{c}333 \\
(4.41)\end{array}$ \\
\hline Bulgaria & $\begin{array}{c}372 \\
(10.52)\end{array}$ & $\begin{array}{c}541 \\
(13.49)\end{array}$ & $\begin{array}{c}913 \\
(12.10)\end{array}$ \\
\hline Croatia & $\begin{array}{c}367 \\
(10.38)\end{array}$ & $\begin{array}{c}367 \\
(9.15)\end{array}$ & $\begin{array}{c}734 \\
(9.73)\end{array}$ \\
\hline Czech Republic & $\begin{array}{c}634 \\
(17.93)\end{array}$ & $\begin{array}{c}803 \\
(20.02)\end{array}$ & $\begin{array}{c}1,437 \\
(19.04)\end{array}$ \\
\hline Estonia & $\begin{array}{c}167 \\
(4.72)\end{array}$ & $\begin{array}{c}288 \\
(7.18)\end{array}$ & $\begin{array}{c}455 \\
(6.03)\end{array}$ \\
\hline Hungary & $\begin{array}{c}374 \\
(10.58)\end{array}$ & $\begin{array}{c}268 \\
(6.68)\end{array}$ & $\begin{array}{c}642 \\
(8.51)\end{array}$ \\
\hline Poland & $\begin{array}{c}589 \\
(16.66)\end{array}$ & $\begin{array}{c}481 \\
(11.99)\end{array}$ & $\begin{array}{c}1,070 \\
(14.18)\end{array}$ \\
\hline Serbia & $\begin{array}{c}309 \\
(8.74)\end{array}$ & $\begin{array}{c}370 \\
(9.23)\end{array}$ & $\begin{array}{c}679 \\
(8.99)\end{array}$ \\
\hline Slovakia & $\begin{array}{c}450 \\
(12.73)\end{array}$ & $\begin{array}{c}407 \\
(10.15)\end{array}$ & $\begin{array}{c}857 \\
(11.36)\end{array}$ \\
\hline Slovenia & $\begin{array}{c}163 \\
(4.61)\end{array}$ & $\begin{array}{c}263 \\
(6.56)\end{array}$ & $\begin{array}{c}426 \\
(5.65)\end{array}$ \\
\hline $\begin{array}{l}\text { Total } \\
\text { (Percent) }\end{array}$ & $\begin{array}{c}3,535 \\
(46.85)\end{array}$ & $\begin{array}{c}4,011 \\
(53.15)\end{array}$ & $\begin{array}{l}7,546 \\
(100)\end{array}$ \\
\hline
\end{tabular}

Source: authors' calculations.

The time intervals of different variables make it possible to trace the relationship between IE and EQ for the period of 6 years: from 2010 to 2015. There are no missings in the final sample, so the overall amount of firm-year observations is equal to 45276.

The two general economic sectors comprise of various industries within them. There is a total of 222 industries: 185 industries in the industrial sector and 37 industries in the retail sector.

Considering the segmentation into public and private companies, the data is less balanced in this case: most of the firms are private, as described in Table 4. 
Table 4 Distribution of companies by sector and legal form

\begin{tabular}{lcc}
\hline Sector & $\begin{array}{c}\text { Private companies } \\
\text { Frequency } \\
\text { (Percent) }\end{array}$ & $\begin{array}{c}\text { Public companies } \\
\text { Frequency } \\
\text { (Percent) }\end{array}$ \\
\hline Retail & 3,244 & 291 \\
& $(63.53)$ & $(11.93)$ \\
Industrial & 1,862 & 2,149 \\
& $(36.47)$ & $(88.07)$ \\
Total & 5,106 & 2,440 \\
\hline
\end{tabular}

Source: authors' calculations.

Nevertheless, such a ratio is natural as the overall number of private companies far exceeds public ones in almost every country in the world. It can also be observed that most of public companies $(88.07 \%)$ operate in the industrial sector, which is a characteristic unique to the Eastern European setting.

The only external data acquired separately from the Amadeus data is the Doing Business Index (DBI) which acts as the proxy for the level of economic and business environment. Out of various Doing Business sub-measures we use the Overall DTF (Distance-To-Frontier) as it is an aggregate index. The values are available for all the country-year pairs in the sample.

\section{Research design}

The methods of our research stay in line with the ones from prior studies while expanding further with the help of additional variables and model specifications. Firstly, we obtain three proxies for EQ using two models from prior literature sources and an aggregate measure. Then we compute one proxy for IE and separate it into OI and UI. Having acquired all necessary variables, we investigate the relationship between EQ and IE using a regression model with several control variables. Next, we add a dummy variable to check the impact of the specific economic sector on the relationship. Finally, we examine the fundamental differences between public and private companies by calculating variable averages and looking at dummies.

Prior to estimating any regression, we winsorize all variables (except dummies) on $1 \%$ and $99 \%$ levels to decrease the impact of outliers.

\subsection{Step 1: Measuring earnings quality}

There is a decent number of different models for the calculation of EQ and no model is superior to others (Dechow et al., 2010). To make our research more solid and viable, we compute three distinct proxies for EQ - 2 accrual-based models and an aggregate measure - and later perform the analysis with each proxy separately.

Our first proxy is derived from the performance-matched accruals model by Kothari et al. (2005): 


$$
T A_{i, t}=\beta_{0}+\beta_{1} \text { deltaRev }_{i, t}+\beta_{2} P P E_{i, t}+\beta_{3} R O A_{i, t}+\varepsilon_{i, t}
$$

where $T A_{i, t}$ is total accruals, calculated as the annual change in non-cash current assets minus the annual change in current non-interest-bearing liabilities (i.e. accounts payable and other current liabilities) minus D\&A expenses; deltaRev ${ }_{i, t}$ is the change in operating revenue from the year $t-1$ to the year $t ; P P E_{i, t}$ is property, plant and equipment, proxied with the value of tangible fixed assets; $R O A_{i, t}$ is the ratio of net income to total assets. According to previous research, all variables except $R O A_{i, t}$ are scaled by lagged total assets (Chen et al., 2011). ${ }^{4}$

Following already existing research, we estimate the regression cross-sectionally (for each sector-country-year combination separately) (Chen et al., 2011; Cutillas Gomariz and Sánchez Ballesta, 2014). Residuals of the model are discretionary accruals (unnatural accruals that arise because of earnings management or errors in estimation) and act as proxies for EQ $\left(E Q \_K O T H_{i, t}\right)$. We multiply absolute values of residuals by -1 , so that higher values of residuals represent higher EQ.

Our second proxy for EQ is derived from the McNichols (2002) and Francis et al. (2005) modification of the Dechow and Dichev (2002) accrual-based model:

$$
\begin{aligned}
\text { TCA }_{i, t}=\beta_{0}+ & \beta_{1} \text { OCFprev }_{i, t}+\beta_{2} \text { OCF }_{i, t}+\beta_{3} \text { OCFnext }_{i, t}+\beta_{4} \text { deltaRev }_{i, t} \\
& +\beta_{5} \text { PPE }_{i, t}+\varepsilon_{i, t}
\end{aligned}
$$

where $T C A_{i, t}$ is total current accruals, computed as the annual change in non-cash current assets minus the annual change in current non-interest-bearing liabilities (i.e. accounts payable and other current liabilities); OCFprev $v_{i, t}, O C F_{i, t}$ and $O C F$ next $t_{i, t}$ are cash flows from operations for years $t-1, t$ and $t+1$ respectively $\left(=O C F_{i, t-1}, O C F_{i, t}\right.$ and $\left.O C F_{i, t+1}\right)$, calculated as the sum of net income, D\&A expenses and the annual change in current liabilities, minus the annual change in current assets; deltaRev $v_{i, t}$ is the change in operating revenue from year $t-1$ to year $t ; P P E_{i, t}$ is property, plant and equipment, proxied with the value of tangible fixed assets. All variables are scaled by lagged total assets.

We estimate the regression cross-sectionally for each sector-country-year combination. Residuals of the model are discretionary current accruals and act as proxies for EQ $\left(E Q_{-} D D M_{i, t}\right)$. We multiply absolute values of residuals by -1 , so that higher values of residuals represent higher EQ.

Our third and final proxy for EQ is computed as a simple average of the two previous proxies standardized:

$$
E Q_{-} A V_{i, t}=\frac{E Q_{-} K O T H_{i, t}(\text { standardized })+E Q_{-} D D M_{i, t}(\text { standardized })}{2}
$$

\footnotetext{
${ }^{4}$ Total assets are lagged by 1 period relative to the variable's period.
} 
After the calculation of this proxy, we do not need to adjust its values in any way: initially higher values of $E Q_{-} A V_{i, t}$ represent higher EQ.

\subsection{Step 2: Measuring investment (in)efficiency}

In this research, we use the growth opportunities model to proxy inefficient investment levels. The method was first applied to firm-level investment by Biddle et al. (2009) and was later expanded with some additional factors in the works of Chen et al. (2011) and Fusheng et al. (2015). The model predicts optimal level of investment using financial variables of the company from the previous period, and aligns appropriately with technically similar accrual-based models of EQ.

We implement the following investment model:

$$
\begin{aligned}
\text { Invest }_{i, t}= & \beta_{0}+\beta_{1} \text { InvestLag }_{i, t}+\beta_{2} \text { RevGrowth }_{i, t-1}+\beta_{3} N R G_{i, t-1} \\
& +\beta_{4} \text { NRGxRevGrowth }_{i, t-1}+\beta_{5} \text { Size }_{i, t-1}+\beta_{6} \text { Age }_{i, t-1} \\
& +\beta_{7} \text { Lev }_{i, t-1}+\beta_{8} \text { Slack }_{i, t-1}+\beta_{9} \text { ROA_lag }_{i, t}+\beta_{10} \text { DBI }_{i, t}+\varepsilon_{i, t}
\end{aligned}
$$

where Invest $_{i, t}$ is net investment in property, plant, machinery, equipment and R\&D, proxied as the annual change in total fixed assets plus D\&A expenses at year $t$;

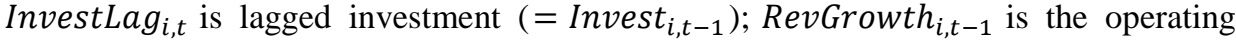
revenue growth rate from $t-2$ to $t-1 ; N R G_{i, t-1}$ is a dummy variable which equals 1 if RevGrowth $_{i, t-1}$ is negative; Size $_{i, t-1}$ is the natural logarithm (ln) of total assets; $A g e_{i, t-1}$ is $\ln$ of firm's age since foundation; $L e v_{i, t-1}$ is financial leverage, calculated as a ratio of total liabilities to total shareholders' funds; Slack $_{i, t-1}$ is a ratio of cash and cash equivalents to total assets; $R O A_{-} l a g_{i, t}$ is return on assets, calculated as a ratio of net income to total assets and also lagged ${ }^{5}\left(=R O A_{i, t-1}\right) ; D B I_{i, t}$ is the Doing Business Index ${ }^{6}$ for the country the firm operates in. The Investment ${ }_{i}$ variables are scaled by lagged total assets.

We estimate the regression cross-sectionally for each sector-country-year combination. Residuals of the model act as proxies for IE $\left(I E_{i, t}\right)$ : these are certain deviations from the expected (optimal) level of investment. Since positive residuals indicate overinvestment and negative residuals indicate underinvestment, after acquiring $I E_{i, t}$ variable we separate it into two sub-variables based on this criterion $\left(O I_{i, t}\right.$ for overinvestment and $U I_{i, t}$ for underinvestment).

We also multiple negative residuals $\left(U I_{i, t}\right)$ by -1 after noting them as underinvestment, so that higher values of both dependent variables indicate lower investment efficiency. For consistency, we also multiply negative values of $I E_{i, t}$ by -1 .

\footnotetext{
${ }^{5}$ We define lagged ROA as a different variable because in other regressions (in accrual-based models) ROA is present as a current period's variable (not lagged).

${ }^{6}$ Out of many Doing Business sub-measures we use the Overall DTF (Distance-To-Frontier) as it is an aggregate general index.
} 


\subsection{Step 3: Exploring the influence of earnings quality on investment efficiency}

Having obtained the proxies for EQ and IE, we proceed onto investigating the impact of EQ on IE. In line with common economic sense as well as prior studies, we test the effect of the previous year's EQ on the current year's IE. Our model specification is the following:

$$
\begin{aligned}
I E_{i, t}=\beta_{0} & +\beta_{1} E Q_{i, t-1}+\sum_{n} \beta_{n} \text { ControlVar }_{n i, t-1}+\sum \text { IndustryFE } \\
& +\sum \text { Country } E+\sum \text { YearF } E+\varepsilon_{i, t}
\end{aligned}
$$

Here $I E_{i, t}$ is either overinvestment $\left(O I_{i, t}\right)$ or underinvestment $\left(U I_{i, t}\right) ; E Q_{i, t-1}$ is either $E Q_{-} K O T H_{i, t-1}, E Q_{-} D D M_{i, t-1}$ or $E Q_{-} A V_{i, t-1}$. We estimate the model for each economic sector (industrial and retail) separately using the pooled OLS regression method with double-clustered standard errors at firm and year levels. Double clustering of standard errors (by firm and year) was first proposed by Petersen (2009): this approach accounts for two-dimensional panel data distribution and makes errors robust both to heteroscedasticity and within-firm serial correlation. Industry, country and time fixed effects (dummies) are also included in the regression.

The pooled OLS method with double-clustered standard errors is used in this study primarily because it provides the best explanatory power and the highest regression significance (compared to FE, RE and GMM models). Moreover, the panel nature of our data is considered and integrated in the model with the help of double-clustering. This econometric approach is also favored in prior literature on the topic.

To purify the main relationship, we add the following lagged control variables $\left(\sum_{n} \beta_{n}\right.$ ControlVar $\left.{ }_{n i, t-1}\right)$ : In of total assets $\left(\right.$ Size $\left._{i, t-1}\right)$; ln of firm's age $\left(A g e_{i, t-1}\right)$; tangibility ratio, calculated as a ratio of tangible fixed assets to total assets $\left(\operatorname{Tang}_{i, t-1}\right)$; cash-to-total assets ratio $\left(\right.$ Slack $\left._{i, t-1}\right)$; ln of average revenue collection period in days, calculated as a ratio of trade receivables to operating revenue, multiplied by 360 $\left(\right.$ CollPer $\left._{i, t-1}\right)$; dummy variable if the firm is public $\left(\right.$ Public $\left._{i, t}\right)$; dummy variable if net income is negative $\left(N N I_{i, t-1}\right)$.

According to our hypothesis $H 1$, the coefficient $\beta_{1}$ is expected to turn out to be negative and significant (or close to significant at conventional levels) for the majority (at least 2) of proxies for EQ, each economic sector and both OI and UI.

Then we move on to our second hypothesis $\mathrm{H} 2$ and look at the distinction between economic sectors more closely, estimating a pooled OLS regression with standard doubleclustered errors at firm and year levels using the whole sample and including a dummy variable for the sectors:

$$
\begin{gathered}
I E_{i, t}=\beta_{0}+\beta_{1} E Q_{i, t-1}+\beta_{2} E Q_{i, t-1} * \text { Sector }_{i}+\sum_{n} \beta_{n} \text { ControlVar }_{n i, t-1} \\
+\sum \text { Sector } F E+\sum \text { CountryFE }+\sum \text { YearF } E+\varepsilon_{i, t}
\end{gathered}
$$


Here Sector $_{i}$ is a dummy variable that equals 1 if the firm is from the industrial sector and 0 if the firm is from the retail sector. The same set of control variables, as well as country, year and sector fixed effects, are included in the regression.

According to hypothesis $H 2$, the coefficient $\beta_{2}$ is expected to be negative and significant (or close to significant at conventional levels) for at least 2 proxies for EQ and both OI and UI.

Finally, we compute averages for $E Q_{-} K O T H_{i, t-1}, E Q_{-} D D M_{i, t-1}, E Q_{-} A V_{i, t-1}, O I_{i, t}$ and we also calculate $U I_{i, t}$ for sub-samples of public and private companies and thus check our hypotheses $H 3$ and $H 4$. For $E Q_{-} K O T H_{i, t-1}, E Q_{-} D D M_{i, t-1}$ and $E Q_{-} A V_{i, t-1}$ averages are expected to be higher for the sub-sample of public companies, and for $O I_{i, t}$ and $U I_{i, t}$ they are expected to be lower.

For $\mathrm{H} 4$ we also examine the coefficient before the variable Public $c_{i, t}$ in previously conducted regressions. This coefficient is expected to be significant and negative.

\section{Results}

\subsection{Descriptive statistics}

Tables 5 and 6 contain descriptive statistics of the variables used in the main regressions (in equations (5) and (6)) separated into sub-samples by economic sector. ${ }^{7}$ Joint descriptive full-sample statistics of major variables, as well as descriptive statistics of secondary variables (used in regressions (1), (2) and (4)), are available in Appendix.

We can see that both $O I$ and $U I$ are on average higher for the industrial sub-sample, which means that retail firms. on average, make more efficient investment decisions. This evidence confirms that the division into sectors was appropriate. It can also be concluded that in Eastern Europe companies tend to overinvest more, while the problem of underinvestment is not that strong: there is a significantly greater number of $O I$ observations and the mean values of $O I$ are higher than the means of $U I$. We explain this phenomenon in detail later when we analyze the regression results. In general, values for $O I$ and $U I$ stay in line with prior research and are lower than in the sample of emerging markets from Chen et al. (2011) or the sample of Spanish firms from Cutillas Gomariz and Sánchez Ballesta (2014), which means that Eastern European firms demonstrate a decent investment efficiency.

As for the 3 EQ proxies, they do not significantly differ between industrial and retail sub-samples. Their average values also agree with previous literature. Table 7 contains the Pearson correlation matrix of examined variables.

\footnotetext{
${ }^{7}$ We present to you already calculated proxies for EQ, OI and UI and do not show the regressions from which we derive them (equations (1), (2) and (4)). These "technical" regressions are only used as a source of proxies in the form of residuals. Moreover, as we estimate these models crosssectionally for each sector-country-year combination, there turn out to be 120 regressions for each of the three models, which is an unrealistically high number to fit in a scientific paper.
} 
Table 5 Descriptive statistics of major variables on the industrial sector sub-sample

\begin{tabular}{lcccccccc}
\hline VARIABLES & $\mathrm{N}$ & Mean & Median & $\begin{array}{c}\text { Std. } \\
\text { Dev. }\end{array}$ & Min & Max & Perc. 10 & $\begin{array}{c}\text { Perc. } \\
90\end{array}$ \\
\hline IE & 24,066 & 0.070 & 0.066 & 0.039 & 0.000 & 0.407 & 0.023 & 0.117 \\
OI & 23,331 & 0.071 & 0.067 & 0.038 & 0.000 & 0.407 & 0.027 & 0.118 \\
UI & 735 & 0.017 & 0.011 & 0.018 & 0.000 & 0.208 & 0.002 & 0.040 \\
EQ_KOTH & 24,066 & -0.050 & -0.046 & 0.033 & -0.285 & -0.000 & -0.090 & -0.011 \\
EQ_DDM & 24,066 & -0.049 & -0.033 & 0.052 & -0.463 & -0.000 & -0.110 & -0.006 \\
EQ_AV & 24,066 & -0.032 & 0.112 & 0.716 & -7.183 & 1.156 & -0.938 & 0.691 \\
Size & 24,066 & 8.570 & 8.525 & 1.687 & 4.779 & 12.591 & 6.440 & 10.859 \\
Age & 24,066 & 2.848 & 2.833 & 0.633 & 0.693 & 5.447 & 2.079 & 3.807 \\
Tang & 24,066 & 0.405 & 0.399 & 0.209 & 0.005 & 0.881 & 0.125 & 0.689 \\
Slack & 24,066 & 0.075 & 0.027 & 0.112 & 0.000 & 0.595 & 0.001 & 0.221 \\
CollPer & 24,066 & 3.885 & 3.975 & 0.877 & 0.976 & 5.622 & 2.846 & 4.862 \\
Public & 24,066 & 0.536 & 1 & 0.499 & 0 & 1 & 0 & 1 \\
NNI & 24,066 & 0.167 & 0 & 0.373 & 0 & 1 & 0 & 1 \\
\hline Source: auther
\end{tabular}

Source: authors' calculations. Note: Higher values of IE, OI and UI indicate lower investment efficiency. Higher values of $E Q \_K O T H, E Q \_D D M$ and $E Q \_A V$ indicate higher earnings quality.

Table 6 Descriptive statistics of major variables on the retail sector sub-sample

\begin{tabular}{lcccccccc}
\hline VARIABLES & $\mathrm{N}$ & Mean & Median & $\begin{array}{c}\text { Std. } \\
\text { Dev. }\end{array}$ & Min & Max & Perc. 10 & $\begin{array}{c}\text { Perc. } \\
90\end{array}$ \\
\hline IE & 21,210 & 0.054 & 0.050 & 0.035 & 0.000 & 0.412 & 0.015 & 0.095 \\
OI & 20,110 & 0.056 & 0.052 & 0.034 & 0.000 & 0.412 & 0.019 & 0.096 \\
UI & 1,100 & 0.016 & 0.011 & 0.016 & 0.000 & 0.117 & 0.002 & 0.037 \\
EQ_KOTH & 21,210 & -0.043 & -0.038 & 0.033 & -0.290 & -0.000 & -0.084 & -0.007 \\
EQ_DDM & 21,210 & -0.051 & -0.034 & 0.057 & -0.481 & -0.000 & -0.116 & -0.006 \\
EQ_AV & 21,210 & 0.037 & 0.210 & 0.764 & -6.298 & 1.159 & -0.902 & 0.783 \\
Size & 21,210 & 7.591 & 7.453 & 1.402 & 4.779 & 12.591 & 5.944 & 9.371 \\
Age & 21,210 & 2.593 & 2.639 & 0.453 & 0.693 & 4.700 & 1.946 & 3.045 \\
Tang & 21,210 & 0.315 & 0.280 & 0.232 & 0.005 & 0.881 & 0.036 & 0.657 \\
Slack & 21,210 & 0.099 & 0.046 & 0.128 & 0.000 & 0.595 & 0.004 & 0.275 \\
CollPer & 21,210 & 2.968 & 3.068 & 1.111 & 0.976 & 5.622 & 1.176 & 4.289 \\
Public & 21,210 & 0.082 & 0 & 0.275 & 0 & 1 & 0 & 0 \\
NNI & 21,210 & 0.169 & 0 & 0.374 & 0 & 1 & 0 & 1 \\
\hline Source: authory
\end{tabular}

Source: authors' calculations. Note: Higher values of IE, OI and UI indicate lower investment efficiency. Higher values of $E Q \_K O T H, E Q \_D D M$ and $E Q \_A V$ indicate higher earnings quality. 
Volume 17, Issue 4, 2017

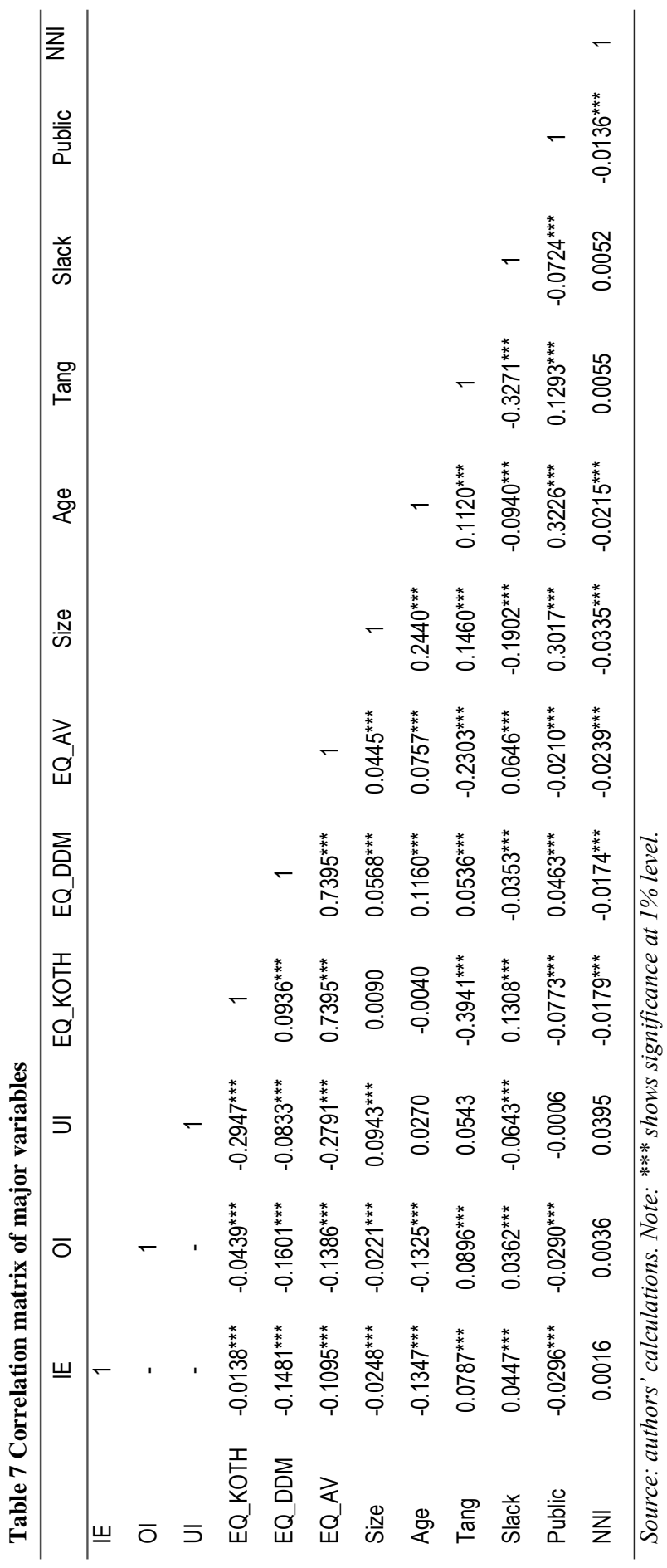


The matrix shows that all 3 proxies for EQ are negatively and significantly on $1 \%$ level correlated with both OI and UI. This indicates that higher EQ may mitigate OI and UI. Also, EQ proxies correlate with each other, which is natural and indicates a consistency within the different EQ measures.

The majority of variables demonstrate high levels of correlation with each other, which is a natural state for firm-level regressions with accounting variables. While estimating regressions, we check the degree of multicollinearity issue using the VIF technique and get all VIFs with values less than 4 , which indicates a common degree of multicollinearity that is not likely to substantially affect the estimations.

\subsection{Results of regressions and sub-sample comparisons}

Tables 8 and 9 present the results of equation (5) estimation: they contain regressions of overinvestment $\left(O I_{i, t}\right)$ and underinvestment $\left(U I_{i, t}\right)$ on different earnings quality proxies $\left(E Q_{-} K O T H_{i, t-1}, E Q_{-} D D M_{i, t-1}\right.$ and $\left.E Q_{-} A V_{i, t-1}\right)$ for retail (Table 8) and industrial (Table 9) sub-samples separately.

The results show that 2 out of 3 EQ proxies (EQ_DDM and $\left.E Q \_A V\right)$ provide a significant $(\mathrm{p}<0.01)$ negative impact on OI for both retail and industrial sub-samples. As for $\mathrm{UI}$, it is significantly $(\mathrm{p}<0.01)$ negatively associated with all $3 \mathrm{EQ}$ proxies for both retail and industrial sub-samples.

Based on this evidence, we are able to fully accept our hypothesis H1. EQ mitigates both OI and UI for companies of retail and industrial sectors of Eastern Europe. These results are completely in accordance with prior studies (Biddle et al., 2009; Chen et al., 2011; Fusheng et al., 2015). The values of $\mathrm{R}^{2}$ are close to the ones obtained from secondary literature, which indicates a consistency and integrity of the topic.

Next we estimate the model necessary for testing our second hypothesis. Table 10 presents the results of equation (6) estimation: it contains regressions of overinvestment $\left(O I_{i, t}\right)$ and underinvestment $\left(U I_{i, t}\right)$ on different earnings quality proxies $\left(E Q_{-} K O T H_{i, t-1}\right.$, $E Q_{-} D D M_{i, t-1}$ and $E Q_{-} A V_{i, t-1}$ ) for the full sample, with $S_{e c t o r}$ dummy included (in its raw form as well as multiplied by EQ proxies in order to obtain interaction coefficients). 
Table 8 Regression of OI and UI on EQ for the retail sub-sample

\begin{tabular}{|c|c|c|c|c|c|c|}
\hline VARIABLES & Ol & $\mathrm{Ol}$ & $\mathrm{Ol}$ & UI & UI & UI \\
\hline EQ_KOTH & $\begin{array}{l}-0.007 \\
(-0.29)\end{array}$ & & & $\begin{array}{c}-0.107^{* * *} \\
(-3.70)\end{array}$ & & \\
\hline$E Q \_D D M$ & & $\begin{array}{c}-0.100^{\star * *} \\
(-4.44)\end{array}$ & & & $\begin{array}{c}-0.028^{\star \star \star} \\
(-3.88)\end{array}$ & \\
\hline$E Q \_A V$ & & & $\begin{array}{c}-0.006^{\star \star *} \\
(-4.14)\end{array}$ & & & $\begin{array}{c}-0.005^{\star * \star} \\
(-4.64)\end{array}$ \\
\hline Size & $\begin{array}{c}-0.001^{* *} \\
(-2.00)\end{array}$ & $\begin{array}{l}-0.001^{*} \\
(-1.84)\end{array}$ & $\begin{array}{c}-0.001^{*} \\
(-1.84)\end{array}$ & $\begin{array}{c}0.001^{* * *} \\
(5.91)\end{array}$ & $\begin{array}{c}0.001^{* * *} \\
(2.94)\end{array}$ & $\begin{array}{c}0.001^{* \star *} \\
(4.12)\end{array}$ \\
\hline Age & $\begin{array}{c}-0.009^{* * *} \\
(-5.07)\end{array}$ & $\begin{array}{c}-0.008^{\star * *} \\
(-4.71)\end{array}$ & $\begin{array}{c}-0.008^{* \star *} \\
(-4.68)\end{array}$ & $\begin{array}{l}0.001 \\
(0.81)\end{array}$ & $\begin{array}{l}0.000 \\
(0.23)\end{array}$ & $\begin{array}{l}0.001 \\
(0.87)\end{array}$ \\
\hline Tang & $\begin{array}{c}0.015^{\star \star \star} \\
(5.97)\end{array}$ & $\begin{array}{c}0.015^{\star * \star} \\
(9.44)\end{array}$ & $\begin{array}{c}0.011^{* * *} \\
(6.25)\end{array}$ & $\begin{array}{l}-0.001 \\
(-0.15)\end{array}$ & $\begin{array}{l}0.005 \\
(1.61)\end{array}$ & $\begin{array}{l}0.002 \\
(0.67)\end{array}$ \\
\hline Slack & $\begin{array}{c}0.025^{\star * *} \\
(3.83)\end{array}$ & $\begin{array}{c}0.024^{\star \star *} \\
(3.61)\end{array}$ & $\begin{array}{c}0.025^{\star * *} \\
(3.63)\end{array}$ & $\begin{array}{c}-0.009^{*} \\
(-1.66)\end{array}$ & $\begin{array}{c}-0.008^{*} \\
(-1.74)\end{array}$ & $\begin{array}{c}-0.010^{*} \\
(-1.89)\end{array}$ \\
\hline CollPer & $\begin{array}{l}0.000 \\
(0.44)\end{array}$ & $\begin{array}{l}0.000 \\
(0.31)\end{array}$ & $\begin{array}{l}0.000 \\
(0.50)\end{array}$ & $\begin{array}{l}0.000 \\
(0.38)\end{array}$ & $\begin{array}{l}-0.000 \\
(-0.11)\end{array}$ & $\begin{array}{l}0.000 \\
(0.23)\end{array}$ \\
\hline Public & $\begin{array}{c}-0.003^{* \star} \\
(-2.31)\end{array}$ & $\begin{array}{c}-0.004^{* \star} \\
(-2.42)\end{array}$ & $\begin{array}{c}-0.004^{* *} \\
(-2.40)\end{array}$ & $\begin{array}{c}-0.003^{* \star *} \\
(-3.50)\end{array}$ & $\begin{array}{c}-0.003^{* *} \\
(-2.40)\end{array}$ & $\begin{array}{c}-0.003^{* \star *} \\
(-2.59)\end{array}$ \\
\hline NNI & $\begin{array}{c}-0.001^{*} \\
(-1.78)\end{array}$ & $\begin{array}{c}-0.001^{\text {** }} \\
(-2.06)\end{array}$ & $\begin{array}{c}-0.001^{* *} \\
(-1.99)\end{array}$ & $\begin{array}{l}0.001 \\
(0.90)\end{array}$ & $\begin{array}{l}0.001 \\
(0.95)\end{array}$ & $\begin{array}{l}0.001 \\
(0.81)\end{array}$ \\
\hline Intercept & $\begin{array}{l}2.399 \\
(1.16)\end{array}$ & $\begin{array}{l}2.118 \\
(0.96)\end{array}$ & $\begin{array}{l}1.778 \\
(0.80)\end{array}$ & $\begin{array}{c}-2.758^{\star *} \\
(-2.23)\end{array}$ & $\begin{array}{c}-2.617^{\star *} \\
(-2.54)\end{array}$ & $\begin{array}{c}-2.608^{\star *} \\
(-2.10)\end{array}$ \\
\hline Industry FE & YES & YES & YES & YES & YES & YES \\
\hline Country FE & YES & YES & YES & YES & YES & YES \\
\hline Year FE & YES & YES & YES & YES & YES & YES \\
\hline Observations & 20,110 & 20,110 & 20,110 & 1,100 & 1,100 & 1,100 \\
\hline $\mathrm{R}^{2}$ & 0.056 & 0.073 & 0.061 & 0.096 & 0.053 & 0.094 \\
\hline $\mathrm{F}$ & 82.45 & 101.3 & 92.02 & 7.985 & 4.479 & 7.551 \\
\hline$p>F$ & 0.000 & 0.000 & 0.000 & 0.000 & 0.000 & 0.000 \\
\hline
\end{tabular}

Source: authors' calculations. Note: The model was estimated using pooled OLS regression method. T-statistics double-clustered by firm and year robust to both heteroscedasticity and serial correlation in parentheses. *** shows significance at $1 \%$ level, ** shows significance at $5 \%$ level, * shows significance at $10 \%$ level. 
Table 9 Regression of OI and UI on EQ for the industrial sub-sample

\begin{tabular}{|c|c|c|c|c|c|c|}
\hline VARIABLES & Ol & Ol & Ol & UI & UI & UI \\
\hline EQ_KOTH & $\begin{array}{l}0.032 \\
(0.73)\end{array}$ & & & $\begin{array}{c}-0.175^{\star \star *} \\
(-5.45)\end{array}$ & & \\
\hline$E Q \_D D M$ & & $\begin{array}{c}-0.097^{\star \star *} \\
(-13.16)\end{array}$ & & & $\begin{array}{c}-0.019^{* * \star} \\
(-2.81)\end{array}$ & \\
\hline$E Q \_A V$ & & & $\begin{array}{c}-0.004^{\star \star \star} \\
(-3.08)\end{array}$ & & & $\begin{array}{c}-0.007^{* * *} \\
(-4.87)\end{array}$ \\
\hline Size & $\begin{array}{l}-0.001 \\
(-1.04)\end{array}$ & $\begin{array}{l}-0.001 \\
(-0.88)\end{array}$ & $\begin{array}{l}-0.001 \\
(-0.75)\end{array}$ & $\begin{array}{c}0.001^{* * *} \\
(4.59)\end{array}$ & $\begin{array}{l}0.001^{*} \\
(1.86)\end{array}$ & 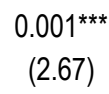 \\
\hline Age & $\begin{array}{c}-0.009^{* * *} \\
(-3.41)\end{array}$ & $\begin{array}{c}-0.008^{\star \star \star} \\
(-3.17)\end{array}$ & $\begin{array}{c}-0.009^{* * \star} \\
(-3.29)\end{array}$ & $\begin{array}{l}-0.001 \\
(-0.73)\end{array}$ & $\begin{array}{l}-0.001 \\
(-0.47)\end{array}$ & $\begin{array}{l}-0.000 \\
(-0.32)\end{array}$ \\
\hline Tang & $\begin{array}{c}0.012^{\star \star \star} \\
(2.75)\end{array}$ & $\begin{array}{c}0.012^{\star * *} \\
(4.64)\end{array}$ & $\begin{array}{c}0.007^{* *} \\
(2.31)\end{array}$ & $\begin{array}{c}-0.011^{\star \star *} \\
(-2.88)\end{array}$ & $\begin{array}{l}0.000 \\
(0.21)\end{array}$ & $\begin{array}{r}-0.006^{* \star *} \\
(-2.63)\end{array}$ \\
\hline Slack & $\begin{array}{c}0.011^{* *} \\
(2.32)\end{array}$ & $\begin{array}{c}0.011^{* * *} \\
(2.75)\end{array}$ & $\begin{array}{c}0.011^{\star * *} \\
(2.60)\end{array}$ & $\begin{array}{l}-0.011^{*} \\
(-1.72)\end{array}$ & $\begin{array}{l}-0.010^{*} \\
(-1.67)\end{array}$ & $\begin{array}{l}-0.008 \\
(-1.23)\end{array}$ \\
\hline CollPer & $\begin{array}{c}-0.003^{\star \star \star *} \\
(-5.32)\end{array}$ & $\begin{array}{c}-0.003^{\star \star \star} \\
(-4.23)\end{array}$ & $\begin{array}{c}-0.003^{* * *} \\
(-4.76)\end{array}$ & $\begin{array}{l}-0.001 \\
(-0.84)\end{array}$ & $\begin{array}{l}-0.001 \\
(-1.24)\end{array}$ & $\begin{array}{l}-0.001 \\
(-0.68)\end{array}$ \\
\hline Public & $\begin{array}{c}-0.010^{* * *} \\
(-2.81)\end{array}$ & $\begin{array}{c}-0.010^{\star \star *} \\
(-2.98)\end{array}$ & $\begin{array}{c}-0.010^{\star * \star} \\
(-3.18)\end{array}$ & $\begin{array}{l}0.000 \\
(0.41)\end{array}$ & $\begin{array}{l}0.000 \\
(0.29)\end{array}$ & $\begin{array}{l}0.001 \\
(0.62)\end{array}$ \\
\hline$N N I$ & $\begin{array}{l}0.000 \\
(0.07)\end{array}$ & $\begin{array}{l}-0.000 \\
(-0.04)\end{array}$ & $\begin{array}{l}0.000 \\
(0.01)\end{array}$ & $\begin{array}{l}0.003 \\
(1.00)\end{array}$ & $\begin{array}{l}0.003 \\
(1.32)\end{array}$ & $\begin{array}{l}0.003 \\
(1.03)\end{array}$ \\
\hline Intercept & $\begin{array}{l}1.634 \\
(0.57)\end{array}$ & $\begin{array}{l}1.240 \\
(0.42)\end{array}$ & $\begin{array}{l}1.217 \\
(0.43)\end{array}$ & $\begin{array}{c}-2.172^{\star * *} \\
(-5.64)\end{array}$ & $\begin{array}{l}-1.117 \\
(-0.92)\end{array}$ & $\begin{array}{l}-0.894 \\
(-1.01)\end{array}$ \\
\hline Industry FE & YES & YES & YES & YES & YES & YES \\
\hline Country FE & YES & YES & YES & YES & YES & YES \\
\hline Year FE & YES & YES & YES & YES & YES & YES \\
\hline Observations & 23,331 & 23,331 & 23,331 & 735 & 735 & 735 \\
\hline $\mathrm{R}^{2}$ & 0.074 & 0.090 & 0.079 & 0.182 & 0.049 & 0.137 \\
\hline $\mathrm{F}$ & 151 & 160.7 & 145.8 & 9.433 & 2.057 & 7.011 \\
\hline$p>F$ & 0.000 & 0.000 & 0.000 & 0.000 & 0.020 & 0.000 \\
\hline
\end{tabular}

Source: authors' calculations. Note: The model was estimated using pooled OLS regression method. T-statistics double-clustered by firm and year robust to both heteroscedasticity and serial correlation in parentheses. $* * *$ shows significance at $1 \%$ level, $* *$ shows significance at $5 \%$ level, * shows significance at $10 \%$ level. 
Table 10 Regression of $\mathrm{OI}$ and UI on EQ for the full sample with Sector dummy

\begin{tabular}{|c|c|c|c|c|c|c|}
\hline VARIABLES & Ol & Ol & Ol & UI & UI & UI \\
\hline \multirow[t]{2}{*}{$E Q \_K O T H$} & -0.007 & & & $-0.111^{* * *}$ & & \\
\hline & $(-0.28)$ & & & $(-3.69)$ & & \\
\hline \multirow[t]{2}{*}{$E Q_{-} D D M$} & & $-0.100^{\star * *}$ & & & $-0.027^{\star * *}$ & \\
\hline & & $(-4.32)$ & & & $(-3.46)$ & \\
\hline \multirow[t]{2}{*}{$E Q \_A V$} & & & $-0.006^{* * *}$ & & & $-0.005^{\star * *}$ \\
\hline & & & $(-4.06)$ & & & $(-4.49)$ \\
\hline \multirow[t]{2}{*}{ EQ_KOTHxSector } & 0.036 & & & $-0.053^{\star *}$ & & \\
\hline & (1.21) & & & $(-2.50)$ & & \\
\hline \multirow[t]{2}{*}{$E Q \_D D M x$ Sector } & & 0.002 & & & 0.009 & \\
\hline & & $(0.08)$ & & & $(0.78)$ & \\
\hline \multirow[t]{2}{*}{$E Q \_A V x$ Sector } & & & 0.001 & & & $-0.002^{* *}$ \\
\hline & & & $(0.84)$ & & & $(-2.01)$ \\
\hline \multirow[t]{2}{*}{ Sector } & $0.024^{* * *}$ & $0.023^{* * *}$ & $0.022^{* * *}$ & $-0.005^{* * *}$ & 0.002 & $-0.002^{*}$ \\
\hline & $(22.93)$ & $(26.07)$ & $(25.54)$ & $(-3.83)$ & $(1.06)$ & $(-1.79)$ \\
\hline \multirow[t]{2}{*}{ Size } & -0.001 & -0.001 & -0.001 & $0.001^{* * *}$ & $0.001^{* * *}$ & $0.001^{* * *}$ \\
\hline & $(-1.37)$ & $(-1.21)$ & $(-1.12)$ & $(8.97)$ & $(3.70)$ & $(5.32)$ \\
\hline \multirow[t]{2}{*}{ Age } & $-0.009^{* * *}$ & $-0.008^{* * *}$ & $-0.009^{* * *}$ & 0.000 & -0.000 & 0.000 \\
\hline & $(-4.37)$ & $(-4.06)$ & $(-4.10)$ & $(0.20)$ & $(-0.15)$ & $(0.54)$ \\
\hline \multirow[t]{2}{*}{ Tang } & $0.014^{\star * *}$ & $0.014^{\star * *}$ & $0.009^{* * *}$ & -0.004 & 0.003 & -0.000 \\
\hline & $(4.88)$ & (8.63) & $(5.23)$ & $(-1.07)$ & $(1.31)$ & $(-0.15)$ \\
\hline \multirow[t]{2}{*}{ Slack } & $0.018^{* * *}$ & $0.018^{* * *}$ & $0.019^{* * *}$ & $-0.009^{* *}$ & $-0.009^{* *}$ & $-0.009^{* *}$ \\
\hline & $(4.94)$ & $(5.02)$ & $(5.05)$ & $(-2.39)$ & $(-2.44)$ & $(-2.30)$ \\
\hline \multirow[t]{2}{*}{ CollPer } & $-0.001^{* *}$ & $-0.001^{* *}$ & $-0.001^{* *}$ & 0.000 & -0.000 & -0.000 \\
\hline & $(-2.39)$ & $(-2.03)$ & $(-2.14)$ & $(0.10)$ & $(-0.54)$ & $(-0.06)$ \\
\hline \multirow[t]{2}{*}{ Public } & $-0.009^{* * *}$ & $-0.009^{* * *}$ & $-0.009^{* * *}$ & $-0.001^{* *}$ & -0.001 & -0.001 \\
\hline & $(-3.19)$ & $(-3.40)$ & $(-3.62)$ & $(-2.17)$ & $(-1.50)$ & $(-1.46)$ \\
\hline \multirow[t]{2}{*}{$N N I$} & -0.000 & -0.001 & -0.001 & $0.002^{*}$ & $0.002^{* *}$ & 0.002 \\
\hline & $(-0.60)$ & $(-0.82)$ & $(-0.77)$ & $(1.72)$ & $(2.04)$ & $(1.63)$ \\
\hline \multirow[t]{2}{*}{ Intercept } & 1.928 & 1.569 & 1.393 & $-2.545^{\star * *}$ & $-2.027^{* *}$ & $-1.944^{* *}$ \\
\hline & $(0.76)$ & $(0.60)$ & $(0.54)$ & $(-3.48)$ & $(-2.16)$ & $(-2.03)$ \\
\hline Country FE & YES & YES & YES & YES & YES & YES \\
\hline Year FE & YES & YES & YES & YES & YES & YES \\
\hline Observations & 43,441 & 43,441 & 43,441 & 1,835 & 1,835 & 1,835 \\
\hline $\mathrm{R}^{2}$ & 0.096 & 0.116 & 0.105 & 0.126 & 0.052 & 0.105 \\
\hline $\mathrm{F}$ & 335.5 & 368.9 & 354.8 & 13.69 & 4.547 & 11 \\
\hline$p>F$ & 0.000 & 0.000 & 0.000 & 0.000 & 0.000 & 0.000 \\
\hline
\end{tabular}

Source: authors' calculations. Note: The model was estimated using pooled OLS regression method. T-statistics double-clustered by firm and year robust to both heteroscedasticity and serial correlation in parentheses. ${ }^{* * *}$ shows significance at $1 \%$ level, $* *$ shows significance at $5 \%$ level, * shows significance at $10 \%$ level. 
In these regressions, we examine the interaction coefficients for EQxSector variables as they are the ones that show what contribution a specific (industrial) sector provides to the relationship between EQ and OI/UI.

We can read from the results that the industrial sector does not significantly strengthen or weaken the relationship between EQ and OI - the coefficients are insignificant at conventional levels. On the other hand, the situation is the complete opposite for UI: according to the coefficients, the impact of EQ on UI strengthens because of the industrial sector for 2 out of $3 \mathrm{EQ}$ proxies $\left(E Q \_K O T H x\right.$ Sector $=-0.053, p<0.05$ and $E Q \_A V x$ Sector $\left.=-0.002, p<0.05\right)$.

Based on this evidence we accept the hypothesis $\mathrm{H} 2$ for underinvestment and reject it for overinvestment. The impact of EQ on UI is significantly stronger in the industrial sector, while for OI the relationship does not change with sectors.

A possible explanation for such phenomenon lies in the fact that OI is significantly higher for industrial companies (which is confirmed by the coefficients for the Sector dummy - all 3 coefficients are significant and positive). Companies in the industrial sector experience overinvestment issues more, which may be connected to the strong risk shifting and empire building problems in the sector: industrial companies in Eastern Europe often get financial and legal support from the government (or are simply stateowned) and therefore have more funding opportunities; the feeling of having such a protection biases management's decisions towards overinvestment and taking additional risks (such as new debt). The presence of these factors diminishes the influence of EQ on OI and levels off potential increases in this relationship (and these increases could happen due to larger degree of accrual accounting employed, better access to capital markets, etc.). As a result, the relationship between EQ and OI does not significantly change in the industrial sector.

Finally, we construct averages for the variables needed to test the hypotheses $H 3$ and H4. Table 11 presents mean and median values of EQ_KOTH, EQ_DDM, EQ_AV,OI and $U I$ for public and private companies separately.

Table 11 Average values of EQ, OI and UI for private and public companies

\begin{tabular}{lcccccc}
\hline & \multicolumn{3}{c}{ Private companies } & \multicolumn{3}{c}{ Public companies } \\
VARIABLES & $\mathrm{N}$ & Mean & Median & $\mathrm{N}$ & Mean & Median \\
\hline EQ_KOTH & 30,636 & -0.050 & -0.050 & 14,640 & -0.045 & -0.045 \\
EQ_DDM & 30,636 & -0.052 & -0.052 & 14,640 & -0.046 & -0.046 \\
EQ_AV & 30,636 & -0.022 & -0.022 & 14,640 & 0.011 & 0.011 \\
OI & 29,430 & 0.066 & 0.066 & 14,011 & 0.062 & 0.062 \\
UI & 1,206 & 0.016 & 0.016 & 629 & 0.016 & 0.016 \\
\hline
\end{tabular}

Source: authors' calculations. Note: Higher values of OI and UI indicate lower investment efficiency. Higher values of EQ_KOTH, EQ_DDM and EQ_AV indicate higher earnings quality. 
We can see that both mean and median values of $E Q \_K O T H, E Q \_D D M$ and $E Q \_A V$ are higher for the sub-sample of public companies. This evidence is sufficient to accept the hypothesis $\boldsymbol{H 3}$. On average, public firms have a higher earnings quality, which is confirmed by all $3 \mathrm{EQ}$ proxies.

As for $O U$ and $U I$, the situation is more vague - the mean and median of these variables do not differ that much between public and private sub-samples. We need to examine additional evidence by returning to Table 10 (which presents regressions of OI and UI on EQ for the full sample with Sector dummy) and looking at the dummy variable Public $_{i, t}$ which equals 1 if the firm is public. For $O I$ in all 3 regressions the coefficient is negative $(-0.009)$ and significant $(\mathrm{p}<0.01)$, which means that $O I$ is significantly lower for public firms. However, for UI coefficients are negative (-0.001) but significant only in 1 regression, and from there we draw the conclusion about the insignificance of the discrepancy in $U I$ between public and private firms.

We can conclude that the hypothesis $H 4$ is accepted for overinvestment, but rejected for underinvestment. OI is significantly lower for the sub-sample of public companies, while UI stays approximately the same.

Such a result may be explained by the fact that underinvestment issues for companies of Eastern Europe are, in general, quite low compared to overinvestment. In this setting of low UI the factor of the company's ownership form does not produce any significant impact: even if it is present, the scale of it is too small as is the scale of UI problems in comparison to OI.

In conclusion, the results, overall, stay in line with previous studies as well as our own expectations. Some results related to hypotheses $H 2$ and $H 4$ are unexpected, but we find explanation for them, taking into account the specificity of Eastern Europe business environment.

\section{Conclusion}

The main results of this study suggest that higher earnings quality mitigates both overand underinvestment for the companies of industrial and retail sectors, which is consistent with prior research on the topic. We also find that in the industrial sector the relationship between earnings quality and underinvestment is stronger compared to the retail sector, which corresponds with our expectations: industrial companies in Eastern Europe tend to use accrual accounting more, have a better access to capital markets and make fundamental long-term investment decisions. All these factors boost the role of earnings quality in mitigating underinvestment.

However, for overinvestment the strength of relationship does not significantly change between the two sectors. We suggest an explanation for this result based on the unique properties of the industrial sector in Eastern Europe: it experiences much more of overinvestment problems compared to the retail sector (according to descriptive statistics), possibly due to the strong state support (both financial and legal) of industrial firms, as well as more available funding opportunities in general. These specific negative factors exceed positive ones and, as a result, the impact of earnings quality on overinvestment does not increase in the industrial sector. 
Finally, we examine the role of firm's legal form (and, therefore, access to capital markets) in earnings quality and investment efficiency. We find that public companies in Eastern Europe have, on average, higher earnings quality and lower overinvestment issues, which is in accordance with prior research and our expectations: public firms are exposed to stricter regulations and investors setting a higher demand for the quality of earnings and investment decisions. Nonetheless, underinvestment issues turn out not to significantly differ depending on the company's status: they stay on the same low level, and due to such a small scale the ownership factor does not prove to have a substantial impact. Firms generally have much stronger overinvestment than underinvestment problems, which is, again, a property unique to the Eastern European environment.

This study continues and expands on the topic of the role of financial reporting quality and earnings quality in the firm-level investment efficiency problem that was first tackled by Biddle and Hilary (2006). We contribute to the issue by placing our research in a unique institutional environment of Eastern Europe and focusing on the factor of specific economic sectors, industrial and retail, that could potentially alter the examined relationship. Apart from the academic relevance, this paper can also be helpful in the professional, practical sphere: it might provide some guidance to the corporates of Eastern Europe in the investigation of specific investment efficiency or earnings quality issues, and provide them with an overview of the problematic.

Disclosure statement: No potential conflict of interests was reported by the authors.

\section{References}

Abel, A. B. (1983). Optimal investment under uncertainty. American Economic Review, 73(1), 228-233.

Allee, K. D., and Yohn, T. L. (2009). The demand for financial statements in an unregulated environment: An examination of the production and use of financial statements by privately held small businesses. Accounting Review, 84(1), 1-25. DOI: 10.2308/accr.2009.84.1.1

Ball, R., Kothari, S. P., and Robin, A. (2000). The effect of international institutional factors on properties of accounting earnings. Journal of Accounting and Economics, 29(1), 1-51. DOI: $10.1016 / \mathrm{S} 0165-4101(00) 00012-4$

Basu, S. (1997). The conservatism principle and the asymetric timeliness of earnings. Journal of Accounting and Economics, 24(1), 3-37. DOI: 10.1016/S0165$\underline{4101(97) 00014-1}$

Biddle, G. C., and Hilary, G. (2006). Accounting quality and firm-level capital investment. Accounting Review, 81(5), 963-982. DOI: 10.2308/accr.2006.81.5.963

Biddle, G. C., Hilary, G., and Verdi, R. S. (2009). How does financial reporting quality relate to investment efficiency? Journal of Accounting and Economics, 48(2-3), 112131. DOI: $10.1016 /$ j.jacceco.2009.09.001 
Bushman, R. M., and Smith, A. J. (2001). Financial accounting information and corporate governance. Journal of Accounting and Economics, 32(1-3), 237-333. DOI: 10.1016/S0165-4101(01)00027-1

Chen, F., Hope, O. K., Li, Q., and Wang, X. (2011). Financial reporting quality and investment efficiency of private firms in emerging markets. Accounting Review, 86(4), 1255-1288. DOI: $10.2308 /$ accr-10040

Cherkasova, V., and Zakharova, E. (2016). Suboptimal investments and M\&A deals in emerging capital markets. Economic Annals, 61(208), 93-120. DOI: 10.2298/EKA1608093C

Collins, D. W., Kothari, S. P., Shanken, J., and Sloan, R. G. (1994). Lack of timeliness and noise as explanations for the low contemporaneuos return-earnings association. Journal of Accounting and Economics, 18(3), 289-324. DOI: 10.1016/01654101(94)90024-8

Cutillas Gomariz, M. F., and Sánchez Ballesta, J. P. (2014). Financial reporting quality, debt maturity and investment efficiency. Journal of Banking and Finance, 40(1), 494506. DOI: $\underline{10.1016 / \mathrm{j} . j \mathrm{~b} \text { bankfin.2013.07.013 }}$

Dayanandan, A., Donker, H., Ivanof, M., and Karahan, G. (2016). IFRS and accounting quality: legal origin, regional, and disclosure impacts. International Journal of Accounting and Information Management, 24(3), 296-316. DOI: 10.1108/IJAIM-11-2015-0075

Dechow, P., Ge, W., and Schrand, C. (2010). Understanding earnings quality: A review of the proxies, their determinants and their consequences. Journal of Accounting and Economics, 50(2-3), 344-401. DOI:10.1016/j.jacceco.2010.09.001

Dechow, P. M., and Dichev, I. D. (2002). The quality of accruals and earnings: The role of accrual estimation errors. Accounting Review, 77(SUPPL.), 35-59. DOI: 10.2308/accr.2002.77.s-1.61

Dechow, P. M., Sloan, R. G., and Sweeney, A. P. (1995). Detecting Earnings Management. The Accounting Review, 70(2), 193-225. DOI: 10.2307/248303

Fazzari, S. M., Hubbard, G. R., and Petersen, B. C. (2000). Investment-Cash Flow Sensitivities Are Useful: A Comment on Kaplan and Zingales. Quarterly Journal of Economics, 115(2), 695-705. DOI: $\underline{10.1162 / 003355300554773}$

Francis, J., Schipper, K., and Vincent, L. (2005). Earnings and dividend informativeness when cash flow rights are separated from voting rights. Journal of Accounting and Economics, 39(2), 329-360. DOI: 10.1016/j.jacceco.2005.01.001

Fusheng, W., Zhibiao, Z., and John, H. (2015). Financial Reporting Quality, Free Cash Flow, and Investment Efficiency. SHS Web of Conferences, 27.

Gugler, K., Ivanova, N., and Zechner, J. (2014). Ownership and control in Central and Eastern Europe. Journal of Corporate Finance, 26, 145-163. DOI: 10.1016/j.jcorpfin.2014.03.001

Hayashi, F. (1982). Tobin's Marginal q and Average q: A Neoclassical Interpretation. Econometrica, 50(1), 213-224. DOI: $\underline{10.2307 / 1912538}$ 
Healy, P., and Palepu, K. (2001). Information asymmetry, corporate disclosure, and the capital markets: A review of the empirical disclostire literature. Journal of Accounting and Economics, 31(1-3), 405-440. DOI: 10.1016/S0165-4101(01)00018-0

Jones, J. J. (1991). Earnings Management During Import Relief Investigations. Journal of Accounting Research, 29(2), 193-228. DOI: $10.2307 / 2491047$

Klapper, L. F., Sarria-Allende, V., and Sulla, V. (2002). Small- and Medium-Size Enterprise Financing in Eastern Europe. World Bank Policy Research Working Paper, (2933). DOI: $10.1596 / 1813-9450-2933$

Kothari, S. P., Leone, A. J., and Wasley, C. E. (2005). Performance matched discretionary accrual measures. Journal of Accounting and Economics, 39(1), 163-197. DOI: 10.1016/j.jacceco.2004.11.002

La Rocca, M., Cariola, A. and La Rocca, T. (2007). Overinvestment and underinvestment problems: determining factors, consequences and solutions. Corporate Ownership and Control, 5(1), 79-95. DOI: 10.22495/cocv5ilp7

McNichols, M. (2002). Discussion of "The quality of accruals and earnings: The role of accrual estimation errors"'. Accounting Review, 77(s-1), 61-69. DOI: 10.2308/accr.2002.77.s-1.61

McNichols, M. F., and Stubben, S. R. (2008). Does earnings management affect firms' investment decisions? Accounting Review, 83(6), 1571-1603. DOI: 10.2308/accr.2008.83.6.1571

Md. Shamimul, H., Normah, O., and Syed Zabid, H. (2015). Corporate attributes and market capitalization. Evidence from Bangladesh. Aestimatio, 11, 92-105. DOI: $\underline{10.5605 / \mathrm{IEB} .11 .4}$

Myers, C. (1977). Determinants of corporate borrowing. Journal of Financial Economics, 5(2), 147-175. DOI: 10.1016/0304-405X(77)90015-0

Myers, S. C., and Majluf, N. S. (1984). Corporate financing and investment decisions when firms have information that investors do not have. Journal of Financial Economics, 13(2), 187-221. DOI: 10.1016/0304-405X(84)90023-0

Ohlson, J. A. (2014). Accruals: An overview. China Journal of Accounting Research, 7(2), 65-80. DOI: 10.1016/j.cjar.2014.03.003

Petersen, M. A. (2009). Estimating standard errors in finance panel data sets: Comparing approaches. Review of Financial Studies, 22(1), 435-480. DOI: 10.1093/rfs/hhn053

Sloan, R. G. (1996). Do stock prices fully reflect information in accruals and cash flows about future earnings? Accounting Review, 71(3), 289-315. DOI: 10.2307/248290

Tobin, J. (1969). A General Equilibrium Approach To Monetary Theory. Journal of Money, Credit \& Banking (Ohio State University Press), 1(1), 15-29. DOI: $\underline{10.2307 / 1991374}$ 


\section{Appendix. Additional descriptive statistics}

Table 1 Descriptive statistics of major variables on the full sample

\begin{tabular}{lcccccccc}
\hline VARIABLES & $\mathrm{N}$ & Mean & Median & $\begin{array}{c}\text { Std. } \\
\text { Dev. }\end{array}$ & Min & Max & $\begin{array}{c}\text { Perc. } \\
10\end{array}$ & $\begin{array}{c}\text { Perc. } \\
90\end{array}$ \\
\hline IE & 45,276 & 0.062 & 0.058 & 0.038 & 0.000 & 0.412 & 0.018 & 0.108 \\
OI & 43,441 & 0.064 & 0.060 & 0.037 & 0.000 & 0.412 & 0.022 & 0.109 \\
UI & 1,835 & 0.016 & 0.011 & 0.017 & 0.000 & 0.208 & 0.002 & 0.039 \\
EQ_KOTH & 45,276 & -0.047 & -0.042 & 0.033 & -0.290 & -0.000 & -0.087 & -0.009 \\
EQ_DDM & 45,276 & -0.050 & -0.033 & 0.054 & -0.481 & -0.000 & -0.113 & -0.006 \\
EQ_AV & 45,276 & -0.000 & 0.155 & 0.739 & -7.183 & 1.159 & -0.921 & 0.742 \\
EQ_KOTHxSector & 45,276 & -0.026 & -0.007 & 0.034 & -0.285 & 0.000 & -0.074 & 0.000 \\
EQ_DDMxSector & 45,276 & -0.026 & -0.004 & 0.045 & -0.463 & 0.000 & -0.076 & 0.000 \\
EQ_AVxSector & 45,276 & -0.017 & 0.000 & 0.522 & -7.183 & 1.156 & -0.499 & 0.534 \\
Size & 45,276 & 8.111 & 7.965 & 1.635 & 4.779 & 12.591 & 6.128 & 10.348 \\
Age & 45,276 & 2.728 & 2.773 & 0.570 & 0.693 & 5.447 & 2.079 & 3.178 \\
Tang & 45,276 & 0.363 & 0.353 & 0.224 & 0.005 & 0.881 & 0.063 & 0.676 \\
Slack & 45,276 & 0.086 & 0.035 & 0.120 & 0.000 & 0.595 & 0.002 & 0.247 \\
CollPer & 45,276 & 3.456 & 3.681 & 1.094 & 0.976 & 5.622 & 1.789 & 4.688 \\
Public & 45,276 & 0.323 & 0 & 0.468 & 0 & 1 & 0 & 1 \\
NNI & 45,276 & 0.168 & 0 & 0.374 & 0 & 1 & 0 & 1 \\
Sector & 45,276 & 0.532 & 1 & 0.499 & 0 & 1 & 0 & 1 \\
\hline Source: authors & calcis & & & & & & &
\end{tabular}

Source: authors' calculations. 
Table 2 Descriptive statistics of secondary variables

\begin{tabular}{|c|c|c|c|c|c|c|c|c|}
\hline VARIABLES & $\mathrm{N}$ & Mean & Median & $\begin{array}{l}\text { Std. } \\
\text { Dev. }\end{array}$ & Min & Max & $\begin{array}{c}\text { Perc. } \\
10 \\
\end{array}$ & $\begin{array}{c}\text { Perc. } \\
90 \\
\end{array}$ \\
\hline$T A$ & 45,276 & -0.035 & -0.036 & 0.142 & -0.517 & 0.455 & -0.184 & 0.115 \\
\hline deltaRev & 45,276 & 0.043 & 0.012 & 0.550 & -1.773 & 2.408 & -0.462 & 0.561 \\
\hline PPE & 45,276 & 0.376 & 0.358 & 0.241 & 0.006 & 1.083 & 0.064 & 0.701 \\
\hline$R O A$ & 45,276 & 4.211 & 2.944 & 9.585 & -29.08 & 36.680 & -4.566 & 15.32 \\
\hline TCA & 45,276 & 0.010 & 0.007 & 0.138 & -0.454 & 0.497 & -0.132 & 0.157 \\
\hline OCFprev & 45,276 & 0.086 & 0.065 & 0.145 & -0.391 & 0.632 & -0.032 & 0.248 \\
\hline OCF & 45,276 & 0.081 & 0.062 & 0.138 & -0.371 & 0.610 & -0.031 & 0.235 \\
\hline OCFnext & 45,276 & 0.080 & 0.061 & 0.135 & -0.370 & 0.594 & -0.029 & 0.231 \\
\hline Invest & 45,276 & 0.061 & 0.029 & 0.116 & -0.179 & 0.666 & -0.014 & 0.175 \\
\hline InvestLag & 45,276 & 0.061 & 0.028 & 0.119 & -0.171 & 0.695 & -0.016 & 0.176 \\
\hline RevGrowth & 45,276 & 0.036 & 0.010 & 0.279 & -0.602 & 1.270 & -0.253 & 0.327 \\
\hline$N R G$ & 45,276 & 0.477 & 0 & 0.499 & 0 & 1 & 0 & 1 \\
\hline NRGxRevGrowth & 45,276 & -0.077 & 0.000 & 0.128 & -0.602 & 0.000 & -0.253 & 0.000 \\
\hline Size & 45,276 & 8.111 & 7.965 & 1.635 & 4.779 & 12.591 & 6.128 & 10.35 \\
\hline Age & 45,276 & 2.728 & 2.773 & 0.570 & 0.693 & 5.447 & 2.079 & 3.178 \\
\hline Lev & 45,276 & 2.413 & 1.026 & 5.879 & -11.45 & 42.210 & 0.153 & 5.346 \\
\hline Slack & 45,276 & 0.086 & 0.035 & 0.120 & 0.000 & 0.595 & 0.002 & 0.247 \\
\hline ROA_lag & 45,276 & 4.211 & 2.944 & 9.585 & -29.08 & 36.680 & -4.566 & 15.32 \\
\hline$D B I$ & 45,276 & 67.876 & 68.380 & 5.509 & 51.96 & 80.440 & 60.60 & 75.66 \\
\hline
\end{tabular}

Source: authors' calculations. Note: This table presents full-sample descriptive statistics of variables used in secondary regressions (regressions (1), (2) and (4) that were estimated only to derive proxies for $E Q$ and $I E)$. 